\title{
An animal cell culture: Advance technology for modern research
}

\author{
Rajeev Nema ${ }^{1}$, Sarita Khare ${ }^{2}$ \\ ${ }^{1}$ Department of Zoology and Biotechnology, Sarojini Naidu Government Girls Post Graduate (Autonomous) College, Bhopal, India \\ ${ }^{2}$ Center for Microbiology \& Bio-Technology Research and Training, Bhopal, India \\ Email: rrsht.nema@gmail.com
}

Received 11 February 2012; revised 22 March 2012; accepted 9 April 2012

\begin{abstract}
At the present time animal cell culture is more significant and multifarious application tool for current research streams. A lot of field assorted from animal cell culture such: stem cell biology, IVF technology, cancer cell biology, monoclonal antibody production, recombinant protein production, gene therapy, vaccine manufacturing, novel drug selection and improvement. In this review conclude animal cell culture as well as its requirements.
\end{abstract}

Keywords: Animal Cell Culture

\section{INTRODUCTION}

Tissue Culture is a general idiom used for the removal of cells, tissues, or organs from an animal and their next placement into an artificial environment conductive to growth. Tissue culture is capable of clear as the growth of tissue or cell separate from the organism. It is also known as techniques of keeping tissues alive and growing in an appropriate culture medium. Growing tissues of living organism outside the body is made possible in an appropriate culture medium, containing mixture of nutrient either in solid or liquid form. At present remarkable association in the field of animal cell culture done by researchers: Human insulin became the earliest recombinant protein to be approved as a therapeutic agent, Human growth hormone produced from recombinant bacteria was established in favor of beneficial use, plasminogen activator (tPA) early recombinant animal cells became commercially accessible, [1]. Historical background in the field of animal cell culture demonstrated in Table 1.

Table 1. \#istorical background of animal cell culture.

\begin{tabular}{|c|c|c|}
\hline Year & Significant work & Scientist \\
\hline 1885 & Maintained embryonic chick cells in a saline culture & Roux \\
\hline 1897 & Demonstrated the survival of cells isolated from blood and connective tissue in serum and plasma & Loeb \\
\hline 1907 & $\begin{array}{l}\text { Cultivated frog nerve cells in a lymph clot held by the "hanging drop" method and observed the growth of } \\
\text { nerve fibers in vitro for several weeks }\end{array}$ & Harrisone \\
\hline 1911 & First liquid media consisted of sea water, serum, embryo extract, salts and peptones & Lewis and Lewwis \\
\hline 1916 & Proteolytic enzyme trypsin for the subculture of adherent cells & Rous and Jones \\
\hline 1923 & T-flask as the first specifically designed cell culture vessel & Carrel and Baker \\
\hline 1948 & Isolated mouse l fibroblasts which formed clones from single cells & Earle \\
\hline 1949 & Polio virus could be grown on human embryonic cells in culture & Enders \\
\hline 1952 & Continuous cell line from a human cervical carcinoma known as hela (helen lane) cells & Gey \\
\hline 1955 & Nutrient requirements & Eagle \\
\hline 1964 & Hat medium for cell selection & Littlefield \\
\hline 1975 & First hybridoma capable of secreting a monoclonal antibody & Kohlar and Milstein \\
\hline
\end{tabular}




\section{EQUIPMENT REQUIRED FOR CELL CULTURE}

\subsection{Laminar Flow Hoods}

There are two types of laminar flow hoods, vertical and horizontal. The vertical hood, also well-known as a biology safety cabinet, is effective for harmful organisms since Horizontal hoods are designed such that the air flows directly at the operator hence they are not useful for working with hazardous organisms but are the best protection for cultures. Both types of hoods have continuous displacement of air that passes through a HEPA (high efficiency particle) filter use for the purpose of removes particulates from the air. In a vertical hood, the filtered air blows down from the top of the cabinet; in a horizontal hood, the filtered air blows out at the operator in a horizontal fashion. The hoods are equipped with a short-wave UV light that can be turned on for a few minutes to sterilize the surfaces of the hood, but be aware that only exposed surfaces will be accessible to the UV light. Do not put your hands or face near the hood when the UV light is on as the short wave light can cause skin and eye damage. The hoods should be turned on about 10 - 20 minutes before being used (Figure 1).

\section{2. $\mathrm{CO}_{2}$ Incubators}

Cells are grown-up in an atmosphere of $5 \%-10 \% \mathrm{CO}_{2}$ because the medium used is buffered with sodium bicarbonate/carbonic acid and the $\mathrm{pH}$ must be firmly maintained. Cells are thought to left out of the incubator for as undersized time as possible and the incubator doors should not be opened for very long. The humidity must also be maintained for individuals cells' growing in tissue culture dishes so a pot of water is kept filled at the entire times (Figure 2).

\subsection{Microscopes}

Inverted phase contrast microscopes used for visualizing the cells. Microscopes must be kept enclosed and the

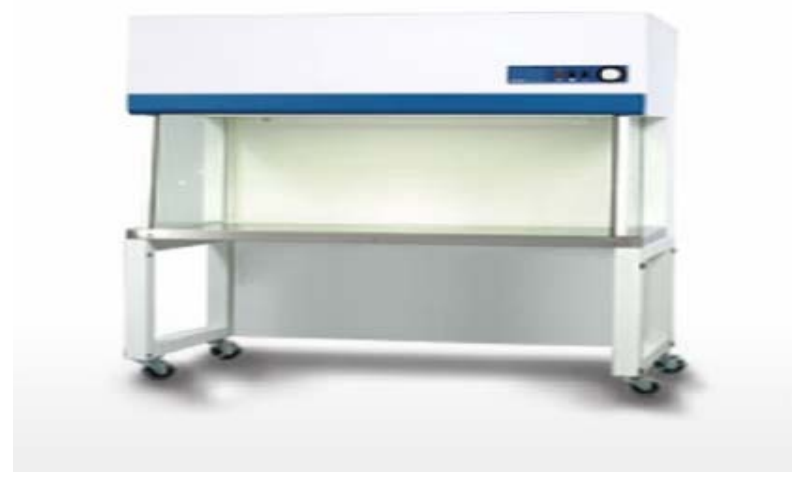

Figure 1. Laminar flow hoods. lights turned down at the same time as not in use. Because the cells are found on bottom of the tissue culture flask that is by use of an inverted microscope is important to absorb cell culture in vitro. The culture media remains above the growing cells plats. If such plates are put over the stage of an ordinary microscope, the growing cells, at bottom cannot be observed. Therefore, the inverted microscope is used for the intention (Figure 3).

\subsection{Vessels}

Anchorage dependent cells have compulsory of a nontoxic, biologically inert, and optically visible surface that will allow cells to attach and allow improvement for the duration of growth. These consist of petri dishes, multiwell plates, microtiter plates, roller bottles, and screwcap flasks-T-25, T-75, T-150 ( $\mathrm{cm}^{2}$ of surface area) (Figure 4).

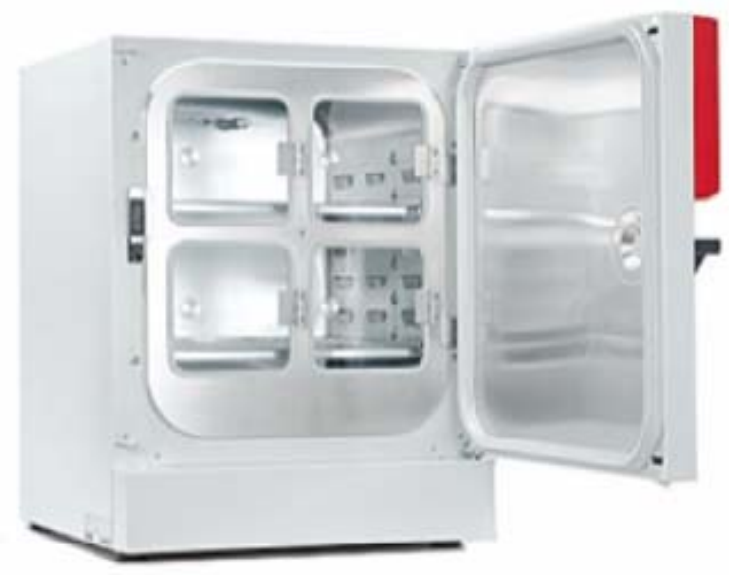

Figure 2. $\mathrm{CO}_{2}$ incubators.

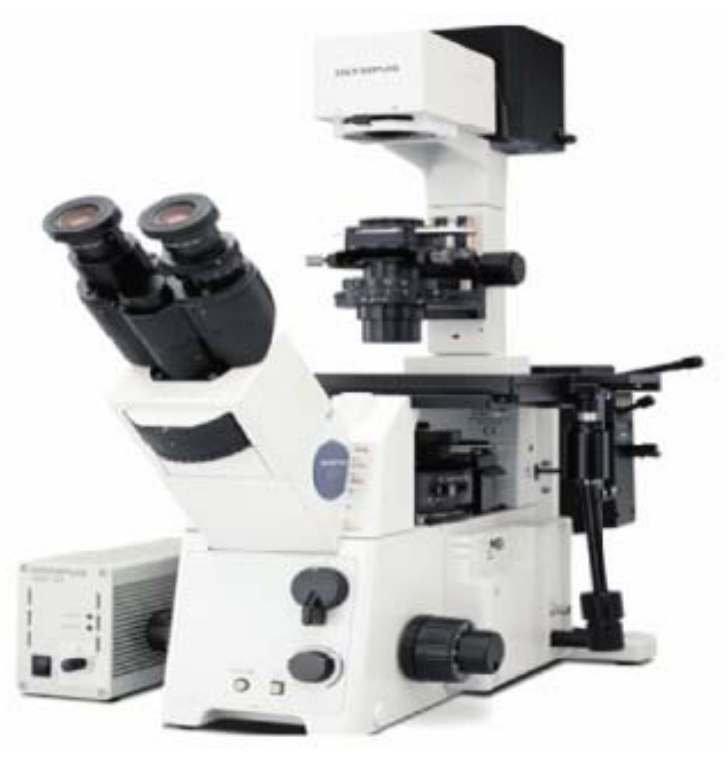

Figure 3. Inverted microscopes. 


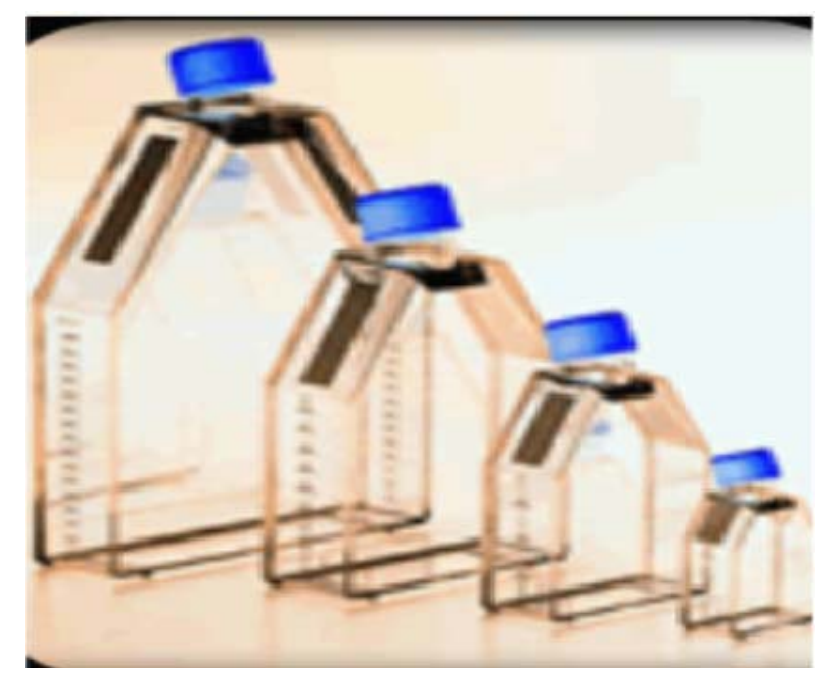

Figure 4. Vessels.

\subsection{Centrifuges}

There are different types of centrifuges based on speed. A low speed centrifuge is needed for most of the cell culture. The separated beads of cells are disrupted simply by a gentle breaking action. Frequently cells are centrifuged at $20^{\circ} \mathrm{C}$ because of motor evolves heat which rises the temperature; therefore make use of low temperature centrifugation is preferred so that the cells should not be exposed to elevated temperature (Figure 5).

\subsection{Freeze}

Freezing or solidification is a phase change in which a liquid turns into a solid when its temperature is lowered under its freezing point. The render null and void procedure is melting. Human gametes and embryos can survive freezing and are viable for up to 10 years, a process known as cryopreservation. Investigational attempts to freeze human beings for later revitalization are known as cryonics (Figure 6).

\section{SUBSTRATES IN FAVOR OF CELL DEVELOPMENT}

There are numerous types of vertebrate cell that have need of support for their development in vitro otherwise they will not grow appropriately. Such cell are called anchorage-dependent cell. Used for that reason a large number of substrate which possibly will necessitate for their enlargement (e.g. glass, palladium, metallic surfaces), nonadhesive (e.g. agar agrose, etc.).

\section{MEDIA REQUIREMENT FOR CELL CULTURE}

When artificial environment formed in the laboratory is in generally known at the same time as media. A media

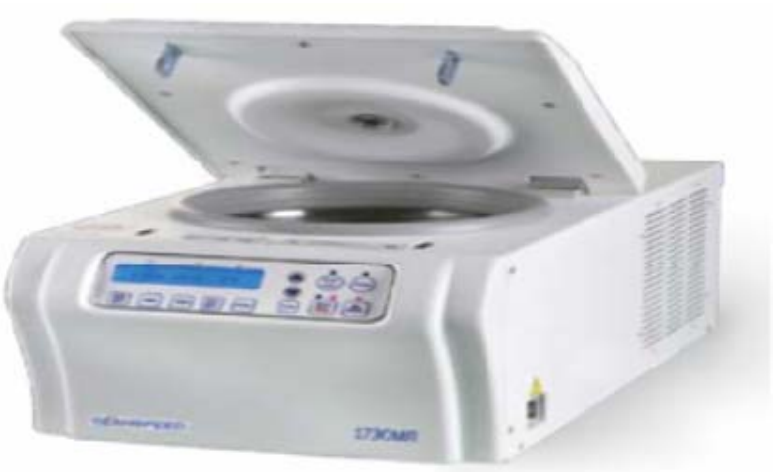

Figure 5. Centrifuges.

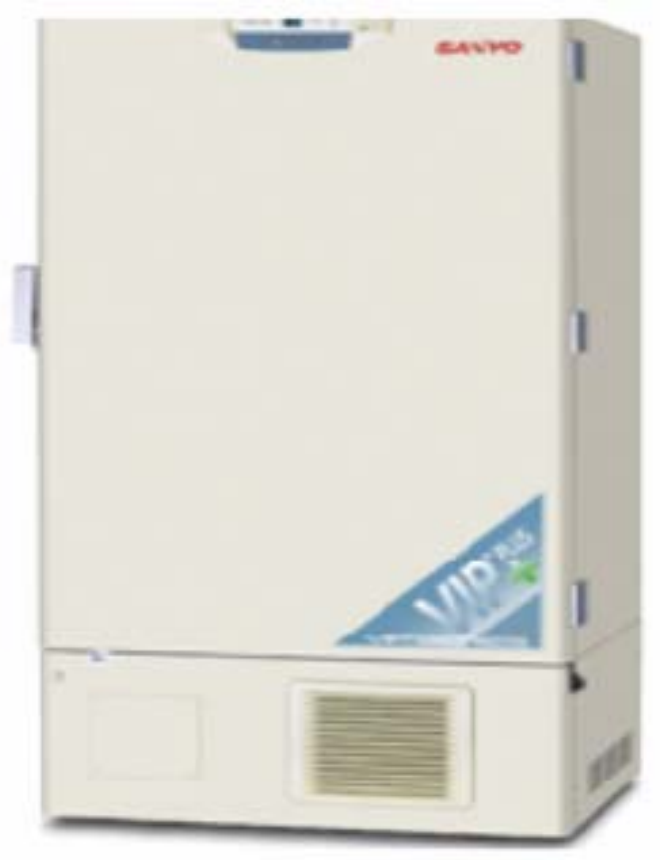

Figure 6. Freezer.

comprises an appropriate source of energy for the cells which they can easily utilize and compounds which regulate the cell cycle. The choice of media is cell type specific and often empirical and there is no "all purpose" medium. It should provide many nutrients, buffering capacity, isotonic, and should be sterile. Characteristics and compositions of the cell culture media vary depending on the particular cellular Requirements. Important parameters include osmolarity, $\mathrm{pH}$, and nutrient formulations.

\subsection{Basic Components in the Culture Media}

Most animal cell culture media are generally having following 10 basic components and they are as follows: Energy sources: Glucose, Fructose, Amino acids, Nitrogen sources: Amino acids. 
The various types of media used for tissue culture may be grouped into two broad categories:

1) Natural media;

2) Artificial media.

\subsubsection{Natural Media}

These media consist solely of naturally occurring biological fluids and are of the following three types:

1) Clots;

2) Biological fluids;

3) Tissue extracts.

\subsubsection{Artificial Media}

Different artificial media have been devised to serve one of the following purposes:

1) Immediate survival (a balanced salt solution, with specified $\mathrm{pH}$ and osmotic pressure is adequate);

2) Prolonged survival (a balanced salt solution supplemented with serum, or with suitable formulation of organic compounds);

3) Indefinite growth;

4) Specialized functions.

\subsection{A Variety of Artificial Media Developed for Cell Cultures May Be Grouped into the Subsequent Four Classes}

1) Serum containing media;

2) Serum free media;

3) Chemically defined media;

4) Protein free media.

\section{CULTURE ENVIRONMENTS}

One of the major advantages of cell culture is the capability to manipulate the physicochemical (i.e., temperature, $\mathrm{pH}$, osmotic pressure, $\mathrm{O}_{2}$ and $\mathrm{CO}_{2}$ tension) and the physiological environment (i.e., hormone and nutriaent concentrations) in which the cells proliferate. Culture environment is a very responsible for cell growth and their maintenance. (Invitrogen Cell Culture Basics). Some specific part discussed below:

\section{1. $\mathrm{pH}$}

Most normal mammalian cell lines grow well at pH 7.4, and there is very little variability among different cell strains. However, some transformed cell lines have been shown to grow better at slightly more acidic environments (pH 7.0 - 7.4), and some normal fibroblast cell lines prefer slightly more basic environments $(\mathrm{pH} 7.4$ 7.7). In laboratory $\mathrm{pH}$ control by $\mathrm{pH}$ meter (Figure 7).

\section{2. $\mathrm{CO}_{2}$}

$\mathrm{CO}_{2}$-bicarbonate based buffer. For the reason that the $\mathrm{pH}$ of the medium is dependent on the delicate balance of dissolved carbon dioxide $\left(\mathrm{CO}_{2}\right)$ and bicarbonate $\left(\mathrm{HCO}_{3}\right)$, changes in the atmospheric $\mathrm{CO}_{2}$ can alter the $\mathrm{pH}$ of the medium. Most researchers usually use 5\% - 7\% $\mathrm{CO}_{2}$ in air; $4 \%-10 \% \mathrm{CO}_{2}$ is common for most cell culture experiments. However, each medium has a recommended $\mathrm{CO}_{2}$ tension and bicarbonate concentration to achieve the correct $\mathrm{pH}$ and osmolality; refer to the media manufacturer's instructions for more information. Inside laboratory condition $\mathrm{CO}_{2}$ concentration controlled by $\mathrm{CO}_{2}$ incubator shaker (Figure 8).

\subsection{Temperature}

The majority human and mammalian cell lines are maintained at $36^{\circ} \mathrm{C}$ to $37^{\circ} \mathrm{C}$ for optimal growth while Avian cell lines need $38.5^{\circ} \mathrm{C}$ in favor of maximum growth. Even though these cells can also be maintained at $37^{\circ} \mathrm{C}$, they will grow further slowly but Cell lines derived from cold-blooded animals (e.g., amphibians, cold-water fish) bear an extensive temperature vary between $15^{\circ} \mathrm{C}$ and $26^{\circ} \mathrm{C}$.

\section{TYPES OF CELLS}

On the basis of morphology or functional characteristics

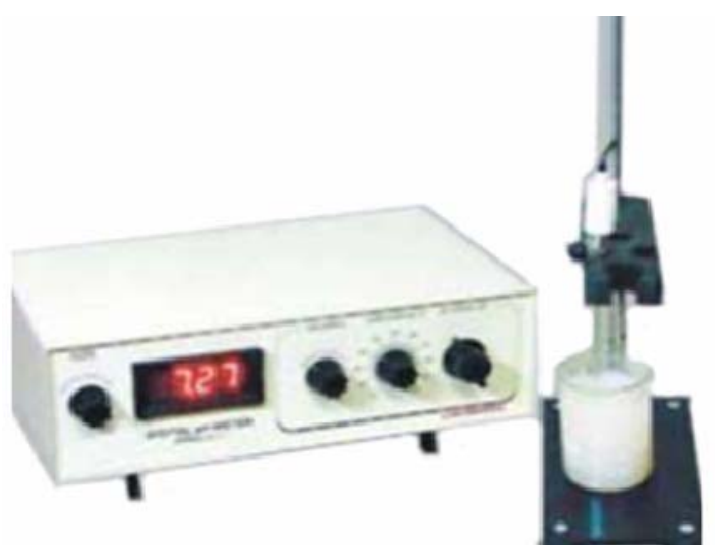

Figure 7. $\mathrm{pH}$ meter.

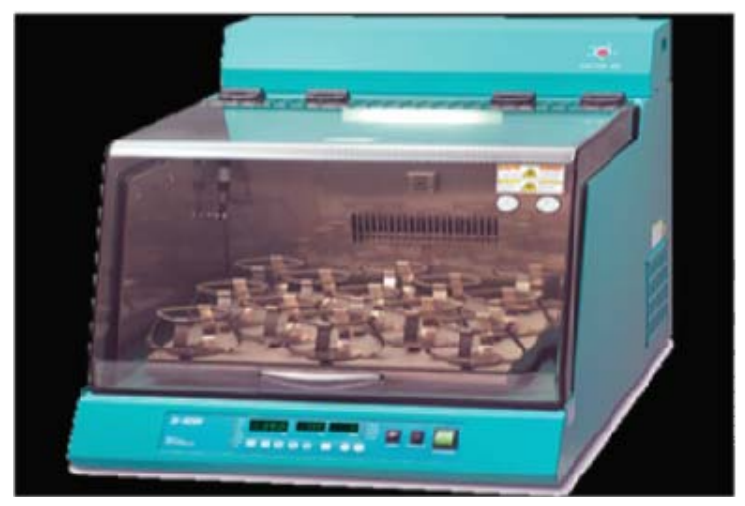

Figure 8. Incubator shaker. 
three type cell considered for cell culture.

\subsection{Epithelial Cell}

Attached to a substrate and appears flattened and polygonal in shape (Figure 9).

\subsection{Lymphoblast Cell}

Cells do not attach; remain in suspension with a spherical shape (Figure 10).

\subsection{Fibroblast Cell}

Cells attached to a substrate; appears elongated and bipolar (Figure 11).

\section{PROCEDURE OF CELL CULTURE}

\subsection{Primary Cell Culture}

Primary cell culture is first cultivation of cell in synthetic condition [2]. Primary cultures, which be obtained straight

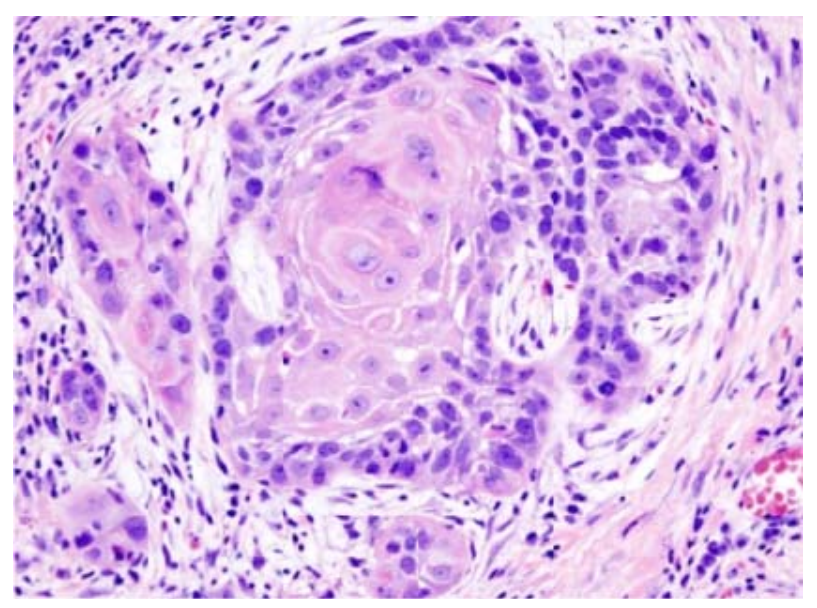

Figure 9. Epithelial cell.

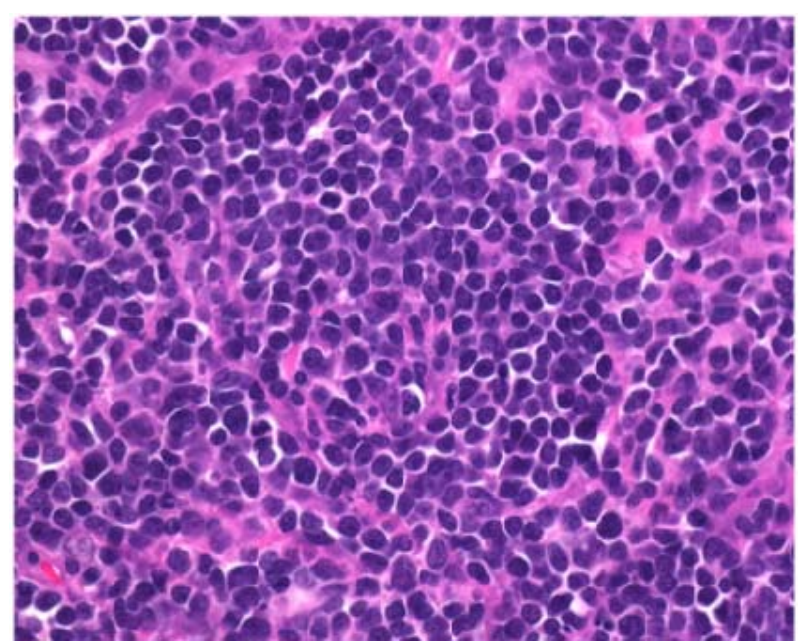

Figure 10. Lymphoblast cell. forwardly from an animal furthermore be capable of maintain the Differentiated state for an undersized period (2). Three Basic Steps of primary tissue culture.

- Isolation of tissue.

Disaggregation of cells-[1] Chemical disaggregation

(2) Mechanical disaggregation (Figure 12).

- Incubation in addition to growth.

\subsection{Subculture (Passaging)}

In animal cell culture a subculture is a new cell culture made by transferring some or all cells from a previous culture to fresh growth medium. This action is called subculturing or passaging the cells [3].

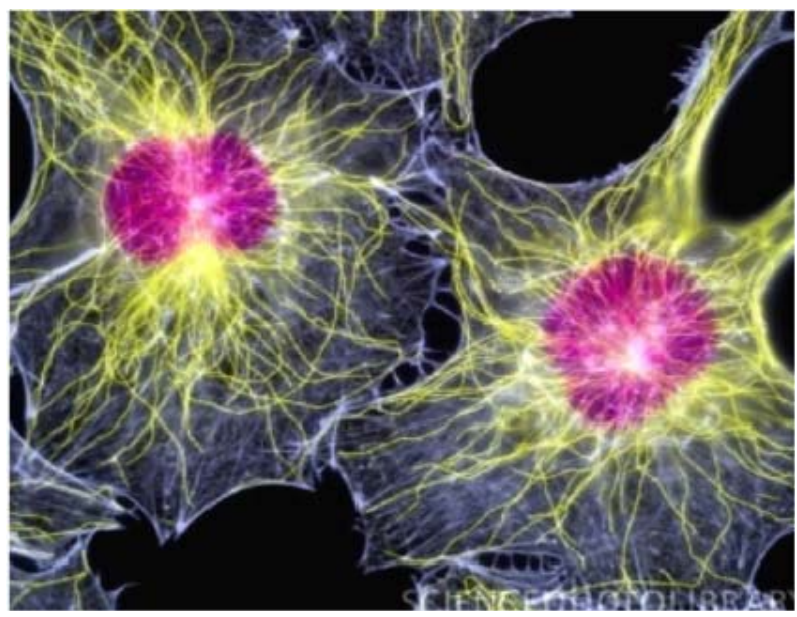

Figure 11. Fibroblast cell.

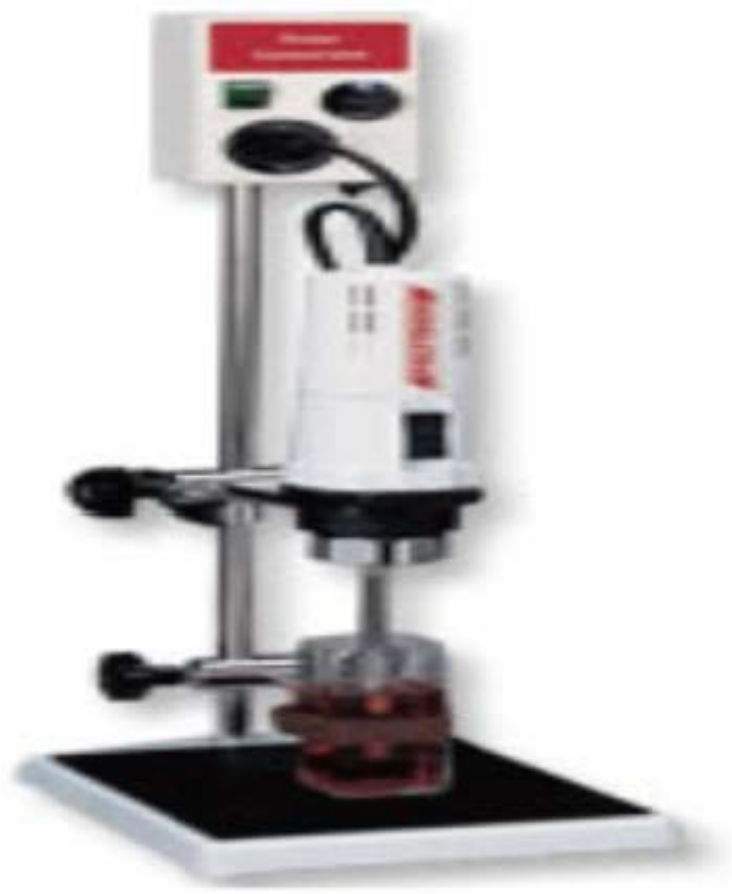

Figure 12. Tissue homogenizing. 


\subsection{Monolayer Culture}

At what time the bottom of the culture vessel is covered by means of a continuous layer of cells, frequently one cell in thickness, they are referred to as monolayer cultures [4].

\subsection{Suspension Cultures}

A few of the cells which are non-adhesive e.g. cells of leukemia or convinced cells which can be mechanically kept within suspension, can exist propagated in suspension. There are certain applications in propagation of cells by suspension culture process.

\subsection{Type of Cell Culture}

\subsubsection{Anchorage Dependent Cell Culture}

Cells shown to necessitate attachment for growth are set to be anchorage dependent cells. The adherent cells are typically derived from tissues of organs such as kidney where they are immobile in addition to embedded in connective tissue. They cultivate adhering to the cell culture.

\subsubsection{Anchorage Independent Cell Culture}

Cells which make not required attachment for growth or do not attach to the surface of the culture vessels are anchorage independent cells/suspension cells [5]. Each and every one suspension cultures are derived from cells of the blood system for the reason that these cells are furthermore suspended in plasma in vitro e.g. lymphocytes [6].

\section{CELL LINE}

A cell line arises from a primary culture at the time of the first successful subculture. The term cell line implies that cultures from it consist of lineages of cells originally present in the primary culture [3].

On the basis of the life span of culture, the cell lines are categorized into two types.

\subsection{Finite Cell Lines}

Cell lines which encompass a restricted life span and exit from beginning to end a restricted number of cell generations (frequently 20 - 80 population doublings) be wellknown as finite cell lines.

\subsection{Continuous Cell Lines}

Cell lines transformed under laboratory surroundings or in vitro culture environment give rise in the direction of continuous cell lines. The cell lines demonstrate the property of ploidy (aneupliody or heteroploidy), lack of contact inhibition and anchorage dependence. They produce in monolayer or suspension type. The growth rate is fast and doubling-up time is 12 - 24 hours.

\section{PRESERVATION AND STORAGE}

\section{Cryopreservation}

Liquid $\mathrm{N}_{2}$ is used to preserve tissue culture cells, either in the liquid phase $\left(-196^{\circ} \mathrm{C}\right)$ or in the vapor phase $\left(-156^{\circ} \mathrm{C}\right)$. Toward minimize the effects of freezing, several precautions are taken. First, a cryoprotective agent which lowers the freezing point, such as glycerol or DMSO, is added. A typical freezing medium is $90 \%$ serum, $10 \%$ DMSO. In addition, it is best to use healthy cells that are growing in log phase and to replace the medium 24 hours before freezing. Also, the cells are slowly cooled from room temperature to $-80^{\circ} \mathrm{C}$ to allow the water to move out of the cells before it freezes. The effect of the isopropanol is to allow the tubes to come to the temperature of the freezer slowly, at about $1^{\circ} \mathrm{C}$ per minute. Cells are stored at liquid nitrogen temperatures because the growth of ice crystals is retarded below $-130^{\circ} \mathrm{C}[7,8]$ (Figure 13).

\section{CELL CULTURE POSSIBLE PROBLEMS}

Protection of aseptic condition is one of the most complex challenges in tissue culture there are quite a lot of rout to contamination which includes malfunction in the sterilization procedures used for glassware \& pipettes, particulates cross contamination of air inside the room, weakly maintained incubation, inappropriate handling.

\subsection{Cell Culture and Cross-Contamination}

Cell line cross-contamination can be a trouble for scientists working through cultured cells. Studies propose anywhere starting $15 \%$ - $20 \%$ of the instance; cells used in experiments have been misidentified or contaminated with another cell line $[9,10]$ troubles with cell line crosscontamination have even been detected in lines from the NCI-60 panel, which are used regularly for drug screening

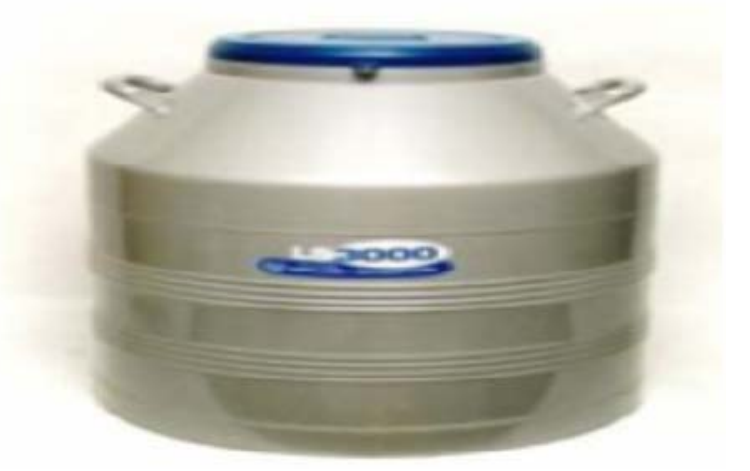

Figure 13. Liquid $\mathrm{n}_{2}$ tank. 
studies [11,12]. Number of contaminants, from microbiological, most of the fungal and bacterial contamination quickly overwhelms a culture and is usually visible to the naked eye within a short period of time.

\subsection{Bacteria and Fungi Contamination}

Microorganisms are the most frequent cell culture contaminators for the reason that they thrive in all environments and are effortlessly moveable from any exterior source such as laboratory instruments, gloves or clothing toward the cells. They grow fast and can be easily seen beneath the microscope. Illustration indicators of contamination include media color change because of a shift in $\mathrm{pH}$, turbidity, presence of non-cellular material, cell vacuolization, or constant cell lysis and death [13].

\subsection{Mycoplasma Contamination}

Mycoplasma is extremely small bacteria-like organisms that are difficult contaminators of cell cultures. Mycoplasma has the capability to alter the host cell culture's morphology, function, metabolism, growth and attachment to the culture vessel. For that reason, the integrity of any experiments performed with mycoplasma-contaminated cells is doubtful because the host cells are not performing normally $[14,15]$.

\subsection{Chemical Contamination}

Chemical contamination is the occurrence of any lifeless substance in the cell culture that causes unfavorable effects to the cells. This may comprise impure media, serum or even water which may contain unwanted endotoxins or organic compounds if not purified. In addition, toxic levels of even vital nutrients can be harmful, and chemical contaminants may possibly also come from unclean storage vessel.

\subsection{Antibiotics}

Accurate working perform, antibiotics should not be used for the routine maintenance of cell lines. In the existence of antibiotics, contamination may be suppressed, but could alter the phenotype or genotype of the cells. Antibiotics are toxic and can alter the biochemistry of the cells. If an infection is not understandable, for the reason that it has been suppressed but not eliminated by antibiotics, all other cultures in the laboratory are at hazard [16].

\section{CONCLUSION}

At present make use of animal cell culture has undergone a significant spreading out from being a purely investigational procedure to become a conventional technological

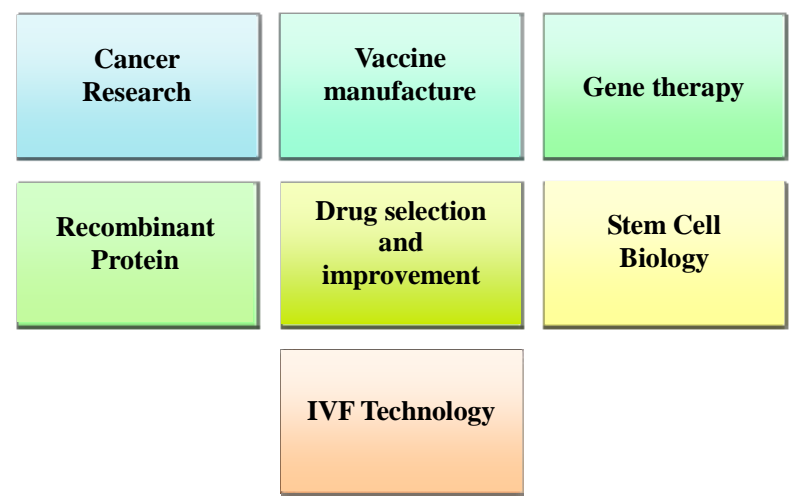

Figure 14. Animal cell culture application.

module of a lot of aspects of biological research. This review summarizes conceptual background and basic techniques of culturing animal cells in a format that is readily easy to get to all researchers in the field. Animal tissue culture functions in therapeutic filed are vast. The evaluation of the cell's response to chemicals, or as a tool to produce cellular-derived protein products that really helps in medical improvement. An animal tissue culture provides an approach to manufacture monoclonal antibody that makes it potential to produce antibody that have specificity controlled toward pathogen. In the field of animal cell culture discovery leads to the opportunity of curing various diseases such as AIDS and cancer. Additional application of animal tissue culture gives a conventional, quick and approachable method for manufacture of well-tolerated and valuable vaccines. Cell culture seems to come with a lot of important towards medical progression. Other than that, there are still differences between in vitro and in vivo system during drug testing and organ transplantation which make it not totally trustworthy.

\section{SIGNIFICANCE OF ANIMAL CELL CULTURE}

The animal cell cultures are used for a diverse range of research and development. These areas are as Figure 14.

\section{ACKNOWLEDGEMENTS}

The authors express gratitude to all member of Center for Microbiology \& Bio-Technology Research and Training for kind support.

\section{REFERENCES}

[1] Surachi, U. (1999) Basic techniques in animal cell culture. Drug Delivery System Workshop, Bangkok.

[2] Freshney, R.I. (2006) Basic principles of cell culture. John Wiley \& Sons, Hoboken.

[3] Freshney, R.I. (2005) Culture of animal cells: A manual of basic technique. 5th Edition, Wiley, New York. 


\section{doi:10.1002/9780471747598}

[4] Phelan, M.C. (1996) Techniques for mammalian cell tissue culture. Current Protocols in Molecular Biology, 3, Appendix 3B.

[5] Chen, J.-Y., Penco, S., Ostrowski, J., Balaguer, P., Pons, M., Starrett, J.E., Reczek, P., Chambon, P. and Gronemeyer, H. (1995) RAR-specific agonist/antagonists which dissociate transactivation and AP1 transrepression inhibit anchorage-independent cell proliferation. The EMBO Journal, 14, 1187-1197.

[6] Glade, P.R. and Hirschhorn, K. (1970) Products of lymphoid cells in continuous culture. The American Journal of Pathology, 60, 483.

[7] Hay, R.J. (1978) Preservation of cell culture stocks in liquid nitrogen. TCA Manual, 4, 787-790. doi:10.1007/BF00918397

[8] Freshney, R.I. (1994) Culture of animal cells. In: Freshney, R.I., Ed., A Manual of Basic Technique, Wiley-Liss, New York, 387-389.

[9] Drexler, H.G. and Uphoff, C.C. (2000) Contamination of cell culture, mycoplasma. Encyclopedia of Cell Technology, 1, 609-627.

[10] Cabrera, C.M., et al. (2006) Identity test: Determination of cell line cross-contamination. Cytotechnology, 51, 45-50.

\section{doi:10.1007/s10616-006-9013-8}

[11] Chatterjee, R. (2007) Cell biology: Cases of mistaken identity. Science, 315, 928-931. doi:10.1126/science.315.5814.928

[12] Liscovitch, M. and Ravid, D. (2006) A case study in misidentification of cancer cell lines: MCF-7/AdrR cells (re-designated NCI/ADR/RES) are derived from OVCAR8 human ovarian carcinoma cells. Cancer Letters, 245, 350-352. doi:10.1016/j.canlet.2006.01.013

[13] Cobo, F., Stacey, G.N., Hunt, C., et al. (2005) Microbiological control in stem cell banks: Approaches to standardization. Applied Microbiology and Biotechnology, 68, 456-466. doi:10.1007/s00253-005-0062-2

[14] McGarrity, G.J. (1976) Spread and control of mycoplasmal infection of cell cultures. In Vitro Cellular \& Developmental Biology_Plant, 12, 643-647. doi:10.1007/BF02797464

[15] McGarrity, G.J., Vanaman, V. and Sarama, J. (1984) Cytogenetic effects of mycoplasmal infection of cell cultures: A review. In Vitro Cellular \& Developmental BiologyPlant, 20, 1-18. doi:10.1007/BF02633326

[16] Masters, J.R. and Stacey, G.N. (2007) Changing medium and passaging cell lines. Nature Protocols, 2, 2276-2284. doi:10.1038/nprot.2007.319 